\title{
A Note on the Defensive Orientation of the Renminbi Exchange Rate Policy*
}

\author{
Wang Jinbin, Li Nan \\ School of Economics, Renmin University of China, Beijing, China \\ Email: wjinbin@ruc.edu.cn, lisouth2003@yahoo.com.cn
}

Received 23 February 2014; revised 26 March 2014; accepted 4 April 2014

Copyright (C) 2014 by authors and Scientific Research Publishing Inc.

This work is licensed under the Creative Commons Attribution International License (CC BY). http://creativecommons.org/licenses/by/4.0/

c) (7) Open Access

\begin{abstract}
History shows that the United States has constantly been the winner in wars of exchange rate since U.S. dollar became the leading international currency. Likewise, the ongoing exchange rate war is bound to increase the costs of maintaining the existing paradigm of international division of labor (IDL henceforth) for emerging economies. In view of the rigid paradigm of IDL and dollar-dominated international monetary system, the defensive tactics of the Renminbi exchange rate policy is in conformity with the modes of China's economic growth and gradual reform, as well as in correspondence with the asymmetric international financial system and trading system. Therefore, using the defensive tactics to reduce the costs of maintaining the existing paradigm of IDL will continue to be the basic policy for RMB exchange rate management in the next few years.
\end{abstract}

\section{Keywords}

Exchange Rate War, Asymmetric Loss Preference, Defensive Orientation, Nominal and Effective Exchange Rate

\section{Introduction}

Since the 1990s, frequent currency crises, especially the Asian financial crisis in 1997-98, have given rise to the sensitiveness of emerging economies to the value changes in their domestic currencies, along with the prevalent emergence of "fear of floating" (Calvo \& Reinhart, 2002). Among them, some Asian export-oriented emerging economies are particularly concerned that the devaluation of their domestic currencies would trigger imported inflation via exchange rates (Ghosh \& Rajan, 2007). However, in recent years, central banks in some emerging Asian economies are concerned more about currency appreciation pressure than about the fear of devaluation.

${ }^{*}$ This article is an interim research outcome of the New Century Excellent Talents Project under the Ministry of Education carried out by the authors, and is also funded by 985 Project of Renmin University of China. 
They have adopted asymmetric intervention behaviors in foreign exchange markets, with a tendency toward "fear of appreciation" (Ramachandran \& Srinivasan, 2007; Pontines \& Rajan, 2008). The "fear of appreciation" has its basis in reality. First, although there have been sharp fluctuations of commodity prices in the last two decades, inflation has not been a major issue facing the developed countries and regions. In the nearly two decades before the global financial crisis in 2008, economies in developed countries and regions basically experienced a Great Moderation stage ${ }^{1}$. Second, accompanying recent years' fast-growing reserves of foreign exchange in some emerging Asian economies, the domestic currency appreciation will, much to the dislike of the central banks, result in the deterioration of central banks' balance sheets through valuation effect ${ }^{2}$. Third, the appreciation of domestic currency will reduce the competitiveness of export products in the international market, which, in some Asian countries, is not conducive to implementing the strategies of export-oriented economic development.

Compared with "fear of floating", the hypothesis of "fear of appreciation" further clarifies central banks' exchange rate policies (ERP) and their asymmetric intervention. This behavior is a new phenomenon involving ERP and behaviors of central banks, a phenomenon that is different from both the fear of national currency devaluation among countries during the financial crisis in the 1990s and the stimulating exports via the "beggarthy-neighbor" policy of competitive devaluation amid the "Great Depression" of 1929-33. This paper will study the Chinese central bank's ERP and practices by using for the first time the asymmetric loss function so as to judge whether these are in line with the hypothesis about this new phenomenon of "fear of appreciation", and to point out that these are rational so far. This paper is divided into four parts: the first part is the introduction; the second is a description of behavior changes in some Asian central banks, with a selection of models; the third comprises descriptions of samples, measurement methods and discussion on measurement results; the last is a brief conclusion.

\section{Change in Central Banks' Behavior and Their Choice of Models}

\subsection{Behavior Change of Some Asian Central Banks after the Asian Financial Crisis}

The currency devaluation crisis of the 1990s can be regarded as being triggered by current account deficits. Mexico's trade deficit in 1994 accounted for 7.2\% of its GDP, and those of Thailand and Malaysia in 1995-96 accounted for roughly $8.0 \%$ of their GDP. These countries almost all adopted portfolio investment inflows or the USD debt to cover their account deficits then. In Thailand, during the three years before the crisis, the lowest proportion of their portfolio investment inflow/trade deficit reached 34.3\% at the lowest level, while investments into the country in other forms during 1994-96 (mainly cross-border lending) was up to $113.2 \%{ }^{3}$ of its trade deficit. In Indonesia and South Korea, portfolio investment inflow/trade deficits reached up to $76.9 \%$ and $91.7 \%{ }^{4}$ respectively. Thus, external imbalances of these countries are adjusted in the currency crisis manner, which is a "shock" therapy. There were countries that contributed to the accumulation of foreign exchange reserves after the crisis. And they did so to avoid repeating past reversal of cross-border portfolio investment caused by currency depreciation expectations as well as high inflation risks in succession. The accumulated foreign exchange reserves have provided intervention and a buffer mechanism to prevent exchange rate fluctuations (Aizenman \& Marion, 2003), which can be explained by factors include, first, self-insurance behaviors with which central banks aim to guard against currency devaluation, via commitment mechanisms (Bussière \& Mulder, 1999), second, precautionary demand motives of foreign exchange transactions (Aizenman \& Lee, 2005), or third, mercantilism trade motivation stimulating economic growth (Dooley, Folkerts-Landau, \& Garber, 2003). The increase of foreign exchange reserves exposed central banks to the opposite concern comparable to that triggered by currency devaluation in crisis, which is the declining competitiveness of export products and the central bank balance sheet deterioration ${ }^{5}$. As domestic currency appreciation gives rise to the shrunken do-

\footnotetext{
${ }^{1}$ There are various studies on the great moderation of the U.S. economy, and earlier comprehensive reviews and discussions can be referred to in Stock \& Watson (2002).

${ }^{2}$ At a particular point of time, with the fixed structure of assets, liabilities, and scales, considering the return on assets in different currencies, the changes in net international investment position caused by changes in exchange rate are defined as valuation effects.

${ }^{3}$ Under this pattern of cross-border lending pegged to and denominated in USD, when domestic currency has a devaluation expectation, the domestic-currency value of debts will be increased; this is called the Original Sin for currency crisis.

${ }^{4}$ Source: calculated on the data from ADB (2008) and Database System by the authors.

${ }^{5}$ There are various studies on the negative impacts on exports by exchange rate fluctuations in Asian countries. See Chit, Rizov, \& Willenbockel (2008).
} 
mestic currency value of foreign currency assets, central banks’ balance sheets will be deteriorated through valuation effect, cutting down local currency value of actual foreign exchange holders. By their increasing taxes or reducing expenditures, Governments will make up for capital losses caused by valuation effect. Besides, central banks can also offset these losses by shouldering the risk of inflation to issue currencies. One study, by calculating in accordance with the amount of foreign exchange reserves in 2003, finds that a 10\% depreciation of USD or a $10 \%$ appreciation of SGD would cost the Singaporean central bank's balance sheet a capital loss as high as $10 \%$ of its GDP that year. Likewise, such capital losses in China except China's Taiwan, Hong Kong and Macau ("China" for short hereafter) and South Korea would both account for about 3\% of their GDP that year (Higgins \& Klitgaard, 2004). Another study indicates that there are remarkable valuation effects in emerging economies (Lane \& Milesi-Ferretti, 2004). Song Xiaojun 宋效军, Chen Debing 陈德兵 and Ren Ruo’en 任若恩 (2006) used the method of valuation effects provided by the IMF (2005) to test China's valuation effect during 19772002. They discovered its existence in the process of China's external balance adjustments, which was negative. Fan Zhiyong 范志勇's research (2008) with a sample period from the beginning of 2005 to March 2008 identified significantly negative valuation effects in foreign exchange assets caused by varied exchange rates. Thus, the valuation effect of currency appreciation has been an issue hardly ignorable for Asian countries with large USD reserves, especially China.

According to China's situation, currency appreciation will undoubtedly cripple the competitiveness of export products. On the one hand, with continuous improvement of the industrial chain of domestic trade, along with an increasing proportion of ordinary trade goods in total trade goods, exchange rate appreciation will significantly reduce the competitiveness of trade goods in international markets (Marquez \& Schindler, 2007; Cheung, Chinn, \& Fujii, 2007). In the light of statistical data available on the Ministry of Commerce website, the share of ordinary trade in China's foreign trade manifests an upward trend. It accounted for $75.9 \%$ of processing trade in 2001, rose to $87.2 \%$ in 2007, and further up to $97.7 \%$ from January to October in 2008, accounting for nearly half of Chinese exports. Therefore, exchange rate appreciation will have significantly negative impacts on China's exports. On the other hand, the appreciation will exert significant negative impacts on labor-intensive manufactured exports that occupy about 20\% - 25\% of the exports (Thorbecke \& Zhang, 2008). According to recent statistics of U.S. Department of Labor, unit labor costs in manufacturing industries in the United States, Japan and Germany fell annually by $1 \%$, 3.5\% and $2.0 \%$ respectively during $2000-2007 .{ }^{6}$ And the statistics indicates that, with the advance of China's income distribution system reform, its labor cost advantage will gradually decline in the future. But the labor-intensive manufacturing industries are still important industries in China when it comes to dealing with the employment issue. It is of critical importance to maintain and enhance its exports to increase employment and reduce the social costs of China's economy.

Furthermore, from the perspective of international division of labor (IDL), developed countries and regions have experienced the "de-industrialization" and "outsourcing" service development process over the past 30 years, along with a sharp drop in the proportion of manufacturing industry. Taking the U.S. manufacturing sector for instance, its share in GDP is currently less than 15\%. As IDL has a certain degree of rigidity, under the current pattern of global economic division of labor, Asian countries will continue with export-oriented development strategies, and it is indispensable to maintain external market demand for these countries to boost growth. "Fear of floating" is a rational choice for a single Asian country, and an overall pegging to USD is beneficial to Asia's trade with the USD zone (Mckinnon \& Schnabl, 2004). Therefore, as a whole, both valuation effect and export-oriented development strategy can be considered as giving rise to asymmetric intervention on foreign exchange markets in some Asian central banks. As for central banks in India, Ramachandran and Srinivasan (2007) revealed their asymmetric intervention on foreign exchange markets for the first time. The study of Srinivasan, Mahambare and Ramachandran (2009) further confirmed the Indian central bank's asymmetric preferences for "fear of appreciation". Based on the monthly data from January 2000 to December 2006, Pontines and Rajan (2008) have studied central bank behaviors in such five countries as India, South Korea, the Philippines, Singapore and Thailand, and also found these sorts of preferences. This research indicates that by comparing central banks' behaviors before and after the 1997-98 Asian financial crisis, ERP and behaviors in these countries have shown drastic changes, which is a shift from the "fear of depreciation" to "fear of appreciation”.

\footnotetext{
${ }^{6}$ Bureau of Labor Statistics (March 3, 2009), International Comparisons of Manufacturing Productivity and Unit Labor Cost Trends 2007, Revised.
} 


\subsection{Model Selection}

Different from the traditional Barro-Gordon Model in which symmetry loss preference is represented by variance, asymmetric loss preference (ALP) indicates that among the central bank's loss functions, compared with the case where actual values of variables are lower than target values or expected values, the central bank tends to give greater weight to the case where the former are higher than the latter. For example, compared with the case where the unemployment rate is lower than the natural unemployment rate, the central bank will endow more weight to the case where the former is higher than the latter, which also shows that the central bank implements more intensive macroeconomic regulation in economic recession than in economic boom. Ruge-Murcia (2003), Nobay and Peel (2003), and Surico (2008) separately studied the Federal Reserve System’s monetary policy preferences by dint of asymmetric preference function, and found the suitability of this function for U.S. monetary policy objectives. For the first time, Ramachandran and Srinivasan (2007) applied asymmetric loss function to the research of the central bank's exchange rate intervention. Details are as follows:

Taking into account the central bank's concern about both changes in foreign exchange reserves (Levy-Yeyati and Sturzenegger, 2007) and exchange rate fluctuations, the loss function can be expressed as:

$$
L_{t}=\frac{1}{2}\left(R_{t}-R_{t}^{*}\right)^{2}+\lambda\left[\frac{\exp \gamma\left(e_{t}-e_{t}^{*}\right)-\gamma\left(e_{t}-e_{t}^{*}\right)-1}{\gamma^{2}}\right]
$$

where $L_{t}$ stands for the loss function, $R_{t}$ foreign exchange reserves, parameter $\lambda>0, e_{t}$ exchange rate, which can be interpreted as nominal exchange rate or nominal effective exchange rate. Variables marked with $*$ are expected values or target values. The second term of Formula (1) with an exponent is called asymmetric loss function, which was initially proposed by Varian (1975), and further elaborated by Zeller (1986). If $\gamma<0$, the same deviation of $e_{t}$ from $e_{t}^{*}$ will engender different loss values, and the losses caused by nominal exchange rate appreciation (indirect quotation) $\left(e_{t}-e_{t}^{*}<0\right)$ of the same extent will be greater than those caused by nominal exchange rate depreciation of the same extent. In other words, the central bank's loss function will endow the nominal exchange rate appreciation with greater weight. If the central bank dislikes changes in nominal exchange rate, let $e_{t}^{*} \equiv 0$. For $e_{t}-e_{t}^{*}<0$ (nominal exchange rate appreciation), $\frac{\partial L_{t}}{\partial e_{t}}=\frac{\lambda}{\gamma}\left[\exp \gamma\left(e_{t}-e_{t}^{*}\right)-1\right]<0$, which expresses that appreciation of domestic currency will increase the central bank's loss function value, or that the central bank fears nominal exchange rate appreciation. When parameter $\gamma \rightarrow 0$, Formula (1) is degraded into the traditional Barro-Gordon Model in which symmetry loss preference is represented by variance; if the parameter $\gamma$ is markedly different from 0 , central bank has asymmetric preferences. When the parameter $\gamma<0$, if the exchange rate is a nominal effective exchange rate, and the nominal effective exchange rate appreciates $\left(e_{t}-e_{t}^{*}>0\right), \frac{\partial L_{t}}{\partial e_{t}}=\frac{\lambda}{\gamma}\left[\exp \gamma\left(e_{t}-e_{t}^{*}\right)-1\right]>0$. This shows that when $\gamma>0$, the central bank dislikes nominal effective exchange rate appreciation without ALP, and the value of exchange rate loss function is mainly represented by the linear part of the second term (exponent term) in Formula (1). Conversely, when $\gamma>0$, the central bank has ALPs for nominal effective exchange rate, whose extent depends on the size of $\gamma$.

The central bank follows the following control path or constraint between exchange rate changes and alteration in reserves:

$$
e_{t}-e^{*}=\theta\left(R_{t}-R_{t}^{*}\right)+\varepsilon_{t}
$$

$\theta$ is a parameter, and $\varepsilon_{t}$ stochastic disturbance term. Optimum reserves are in the form of novel expectation in line with Joneses preferences of foreign exchange reserves accumulation (Machlup, 1966), which can be expressed as follows:

$$
R_{t}^{*}=E_{t-1} R_{t}
$$

Assuming that the central bank can control the reserves and expected reserves to minimize the loss in Formula (1), under the restraints in Formula (2) and additional constraint conditions in Formula (3), the first-order conditions (discretionary solution) are: 


$$
\left(R_{t}-R_{t}^{*}\right)+E_{t-1}\left\{\frac{\lambda \theta}{\gamma}\left[\exp \gamma\left(e_{t}-e_{t}^{*}\right)\right]-1\right\}=0
$$

When $\gamma \rightarrow 0$, there is

$$
\left(R_{t}-R_{t}^{*}\right)+\lambda \theta E_{t-1}\left(e_{t}-e_{t}^{*}\right)=0
$$

In order to overcome the problem that $\gamma$ and $R_{t}-R_{t}^{*}$ need to be identified simultaneously, the exponent part in Formula (4) can be unfolded according to Taylor first-order formula, and there is:

$$
\left(R_{t}-R_{t}^{*}\right)+\lambda \theta E_{t-1}\left(e_{t}-e_{t}^{*}\right)+\frac{\lambda \theta \gamma}{2} E_{t-1}\left(e_{t}-e_{t}^{*}\right)^{2}+\xi_{t}=0
$$

According to novel expectation, we substitute actual value for expected value. Then we can get:

$$
R_{t}-R_{t}^{*}=\mu+\alpha\left(e_{t}-e_{t}^{*}\right)+\beta\left(e_{t}-e_{t}^{*}\right)^{2}+v_{t}
$$

Since the optimal reserves depend on the information set in Formula (3), Formula (2) determines that the target exchange rate also relies on this set, which coincides with the research of Surico (2008), Pontines and Rajan (2008), and so forth. Thus, Formula (7) can be further simplified as:

$$
\Delta R_{t}=\mu+\alpha \Delta e_{t}+\beta\left(\Delta e_{t}\right)^{2}+v_{t}
$$

$\alpha=-\lambda \theta, \quad \beta=-\frac{\lambda \theta \gamma}{2}$, and asymmetric preference parameter $\gamma=\frac{2 \beta}{\alpha} \cdot \mu$ is a constant term, $v_{t}$ an error term, and Formula (8) is an empirically reduced-form regression equation.

\section{Data Description, Econometric Approach, Results and Discussions}

\subsection{Description of Data and Samples}

Taking into account the situation after the 1997-98 financial crisis in Asia, the present study has adopted monthly data from January 1999 to December 2009. The data regarding the RMB nominal exchange rate against the USD and foreign exchange reserves are derived from the IMF database of International Financial Statistics (IFS), and the reserves data of November and December 2009 are obtained from the website of the People's Bank of China; and data on nominal effective exchange rate are derived from the statistics databases of BIS and IFS. Variables in Formula (8) are adopted in the logarithmic differential form.

\subsection{Econometric Approach, Results and Discussions}

As the estimation of reduced-form Equation (8) relies on the information set during $t-1$ period in Formula (6), similar to existing studies, our study adopts GMM method to estimate Formula (8). Table 1 and Table 2 show the econometric results on the RMB nominal exchange rate against the USD (ex) and J test results.

As can be seen from Table 1, the asymmetric preference parameter $\gamma$ for the nominal exchange rate (monthly average value) of RMB against USD is significantly positive under the level of $1 \%$, but only the negative value of $\gamma$ can result in the central bank's ALP of "fear of appreciation". This result is completely contrary to the behaviors of Indian central bank studied by Ramachandran and Srinivasan (2007) and Srinivasan, Mahambare and Ramachandran (2009), and also contrary to the behaviors of the central banks in India, Korea, the Philippines, Singapore, and Thailand researched by Pontines and Rajan (2008). This shows that, with regard to RMB, China's central bank dislikes the appreciation of its nominal exchange rate against the USD. But it has no ALPs. This is because the linear part of the second term in Formula (1) plays the dominant role instead of the exponent part. This conclusion is consistent with what we have observed in reality. During 1999-2005, the nominal exchange rate of RMB against USD was relatively stable, appreciating by about $2 \%$. But since 2005, the rate has now appreciated by around $15 \%$, essentially manifesting an appreciation trend. As can be seen from Table 2, the sample analysis after the reform of the exchange rate regime of RMB in July 2005 has also led to a similar result, where the parameter $\gamma$ is positive without passing the significance test.

The results in Table 3 show that the parameter $\gamma$ for nominal effective exchange rate is significant below the $5 \%$ test level, but the results are inconsistent. When using the nominal effective exchange rate published by 
Table 1. Test results on estimated ex asymmetric preference (sample period: Jan 1999 to Dec 2009).

\begin{tabular}{|c|c|c|c|c|c|c|c|}
\hline set & $e x$ values & Instrumental variables & $\mu$ & $\alpha$ & $\beta$ & $\gamma$ & $J$-test \\
\hline (1) & $\begin{array}{c}\text { average } \\
\text { (monthly average values) }\end{array}$ & $\begin{array}{c}\text { c } R(-1 \text { to }-5,-8,-10) \\
e x(-1 \text { to }-5) e x^{2}(-1 \text { to }-5)\end{array}$ & $\begin{array}{c}2.189^{* * *} \\
(0.148)[0.000]\end{array}$ & $\begin{array}{c}-2.779^{* *} \\
(1.083)[0.012]\end{array}$ & $\begin{array}{c}-1.744^{* *} \\
(0.879)[0.049]\end{array}$ & $\begin{array}{c}1.255^{* * *} \\
(0.186)[0.000]\end{array}$ & $\begin{array}{r}11.097 \\
{[0.746]}\end{array}$ \\
\hline (2) & $\begin{array}{c}\text { End } \\
\text { (end-of-month values) }\end{array}$ & $\begin{array}{c}\text { c } R(-1 \text { to }-4) \text { r }(-6) \\
\text { ex }(-1 \text { to }-5) e^{2}(-1 \text { to }-3)\end{array}$ & $\begin{array}{c}2.051^{* * *} \\
(0.188)[0.000]\end{array}$ & $\begin{array}{c}-1.646 \\
(1.610)[0.309]\end{array}$ & $\begin{array}{c}-0.393 \\
(1.329)[0.768]\end{array}$ & $\begin{array}{c}0.478 \\
(1.163)[0.682]\end{array}$ & $\begin{array}{l}13.334 \\
{[0.272]}\end{array}$ \\
\hline
\end{tabular}

Notes: (1) Set (1) adopts the monthly average exchange rate, and set (2) the end-of-month exchange rate. Newey-West method of fourth order lag is utilized to estimate the covariance matrix, so as to control Heteroscedasticity and serial correlation of error terms; (2) Hansen's J statistic, subject to the null hypothesis of over identification, follows a $\chi^{2}(L-K)$ distribution, in which $L$ and $K$ respectively are the number of instrumental variables and parameters to be estimated. (3) Results of the unit root test (referring to scatter diagrams, we adopt assumption with intercept but without time term trend) show that all variables are stationary series under $1 \%$ significance level; (4) The standard deviation of parameter $\gamma$ is calculated by Delta approximation method; (5) Values in parentheses and square brackets respectively represent the standard deviation and p-value of significance test; ${ }^{* * * *},{ }^{* *}$ and ${ }^{*}$ respectively represent $1 \%, 5 \%$ and $10 \%$ significance level.

Table 2. Test results on estimated ex asymmetric preference (sample period: Aug 2005 to Dec 2009).

\begin{tabular}{|c|c|c|c|c|c|c|c|}
\hline Set & ex values & Instrumental variables & $\mu$ & $\alpha$ & $\beta$ & $\gamma$ & $J$-test \\
\hline (1) & $\begin{array}{c}\text { average } \\
\text { (monthly average values) }\end{array}$ & $\begin{array}{c}\text { c } R(-1 \text { to }-5) \\
e x(-1,-2,-8,-10) e x^{2}(-1,-2)\end{array}$ & $\begin{array}{c}1.686^{* * *} \\
(0.189)[0.000]\end{array}$ & $\begin{array}{c}-1.585 \\
(1.122)[0.166]\end{array}$ & $\begin{array}{c}-0.301 \\
(0.888)[0.736]\end{array}$ & $\begin{array}{c}0.380 \\
(0.861)[0.661]\end{array}$ & $\begin{array}{r}5.933 \\
{[0.747]}\end{array}$ \\
\hline (2) & $\begin{array}{c}\text { end } \\
\text { (end-of-month values) }\end{array}$ & $\begin{array}{c}\text { c } R(-1 \text { to }-5) \\
e x(-1,-2,-8,-10) e x^{2}(-1,-2)\end{array}$ & $\begin{array}{c}1.441^{* * *} \\
(0.243)[0.000]\end{array}$ & $\begin{array}{c}-2.802 \\
(1.687)[0.105]\end{array}$ & $\begin{array}{c}-1.039 \\
(1.292)[0.426\end{array}$ & $\begin{array}{c}0.742 \\
(0.490)[0.137]\end{array}$ & $\begin{array}{c}7.209 \\
{[0.615]}\end{array}$ \\
\hline
\end{tabular}

Notes: the same as for Table 1.

Table 3. Test results on estimated neer asymmetric preference (sample period: Jan 1999 to Dec 2009).

\begin{tabular}{cccccccc}
\hline set & neer values & Instrumental variables & $\mu$ & $\alpha$ & $\beta$ & $\gamma$ & J-test \\
\hline \multirow{2}{*}{ (1) } & \multirow{2}{*}{ From BIS } & c $R(-1$ to $-5,-8,-10)$ & $2.494^{* * *}$ & $-0.479^{* * *}$ & $-0.135^{* *}$ & $0.566^{* *}$ & 15.129 \\
& & neer $(-1$ to -4$)$ neer $^{2}(-1$ to -4$)$ & $(0.134)[0.000]$ & $(0.113)[0.000]$ & $(0.052)[0.010]$ & $(0.275)[0.042]$ & {$[0.299]$} \\
\multirow{2}{*}{ (2) } & \multirow{2}{*}{ From IFS } & c $R(-1$ to $-3,-5,-7)$ & $2.161^{* * *}$ & $-0.439^{* * *}$ & $0.243^{* * *}$ & $-1.104^{* *}$ & 11.318 \\
& & neer $(-1$ to -7$)$ neer ${ }^{2}(-1$ to -4$)$ & $(0.189)[0.000]$ & $(0.113)[0.000]$ & $(0.082)[0.004]$ & $(0.499)[0.029]$ & {$[0.61]$} \\
\hline
\end{tabular}

Note: (1) The neer represents the nominal effective exchange rate of RMB; set (1) adopts the monthly average exchange rate, and set (2) the endof-month exchange rate. Newey-West method of fourth order lag is utilized to estimate the covariance matrix, so as to control Heteroscedasticity and serial correlation of error terms. (2) The Hansen's J statistic, subjected to the null hypothesis of over identification, follows a $\chi^{2}(L-K)$ distribution, in which $L$ and $K$ respectively are the number of instrumental variables and parameters to be estimated. (3) Results of the unit root test (referring to scatter diagrams, we adopt assumption with intercept but without time term trend) show that all variables are stationary series under $1 \%$ significance level. (4) The standard deviation of parameter $\gamma$ is calculated by Delta approximation method. (5) Values in parentheses and square brackets respectively represent the standard deviation and p-value of significance test; ${ }^{* * * * * *}$ and ${ }^{*}$ respectively represent $1 \%$, $5 \%$ and $10 \%$ significance level.

BIS, $\gamma$ is significantly positive, which means that the central bank has a "fear of appreciation" inclination for the nominal effective exchange rate. But when using the nominal effective exchange rate published by IFS, $\gamma$ is significantly negative, which is economically meaningless. In order to further determine whether the central bank has the ALPs on nominal effective exchange rate, this paper adopts additional sample after the exchange rate reform of RMB in July 2005. The results are shown in Table 4.

The results in Table 4 indicate that the parameter $\gamma$ of RMB nominal effective exchange rate is significantly positive below the $5 \%$ test level, no matter whether the data source is BIS or IFS. This shows that the central bank does have "fear-of-appreciation" asymmetric preferences for the nominal effective exchange rate. But the values of $\gamma$ from both were less than 0.5, far below the values in such countries as India and Thailand (range 2.0 - 4.0), where, as studied by Pontines and Rajan (2008), the central banks have significant asymmetric preferences. Therefore, it can be confirmed that China's central bank does have ALP caused by appreciation of nominal effective exchange rate; but because the $\gamma$ value is less than 1 , the preferences should be regarded as considerably muted ones. This conclusion is also consistent with reality. In the long run, after the 1997-98 Asian financial crises, China's nominal effective exchange rate appreciated by about $12 \%$ from January 1999 to the end of 2001; and since the 2008 financial crisis, it appreciated by roughly 5\% from mid-2008 to mid-2009. This indicates that during the recession of global economy after the crisis, the central bank did not try to depreciate nominal effective exchange rate by one-way intervention to improve the competitiveness of export products. 
Table 4. Test results on estimated neer asymmetric preference (sample time: Aug 2005 to Dec 2009).

\begin{tabular}{|c|c|c|c|c|c|c|c|}
\hline set & neer values & Instrumental variables & $\mu$ & $\alpha$ & $\beta$ & $\gamma$ & $J$-test \\
\hline (1) & From BIS & $\begin{array}{c}\text { c } R(-1 \text { to }-5) \\
\text { neer }(-1 \text { to }-5) \text { neer }(-1 \text { to }-5)\end{array}$ & $\begin{array}{c}2.432^{* * *} \\
(0.093)[0.000]\end{array}$ & $\begin{array}{c}-0.352^{* * *} \\
(0.079)[0.000]\end{array}$ & $\begin{array}{c}-0.085^{* * *} \\
(0.028)[0.004]\end{array}$ & $\begin{array}{c}0.484^{* *} \\
(0.214)[0.028]\end{array}$ & $\begin{array}{c}8.200 \\
{[0.514]}\end{array}$ \\
\hline (2) & From IFS & $\begin{array}{c}\text { c } R(-1 \text { to }-5) \\
\text { neer }(-1 \text { to }-5) \text { neer }{ }^{2}(-1 \text { to }-5)\end{array}$ & $\begin{array}{c}2.183^{* * *} \\
(0.171)[0.000]\end{array}$ & $\begin{array}{c}-0.631^{* * *} \\
(0.082)[0.000]\end{array}$ & $\begin{array}{c}-0.109^{* *} \\
(0.044)[0.017]\end{array}$ & $\begin{array}{c}0.347^{* *} \\
(0.167)[0.043]\end{array}$ & $\begin{array}{c}9.361 \\
{[0.745]}\end{array}$ \\
\hline
\end{tabular}

Notes: The same as for Table 3.

Judging from the situation after the exchange rate regime reform in 2005, we can see more clearly found that the central bank has different loss preferences between the nominal exchange rate of RMB against USD and the nominal effective exchange rate.

Figure 1 shows the central bank's different loss preferences between the nominal exchange rate of RMB against USD and the RMB nominal effective exchange rate. The central bank does not like the appreciation of the nominal exchange rate of RMB against USD, but has no asymmetric preferences, which is exhibited by the basic upward trend of this exchange rate. But the central bank has considerably muted asymmetric preferences for the nominal effective exchange rate, especially since the reform of the foreign exchange regime in 2005. This is manifested by the obvious fluctuations of the nominal effective exchange rate, and more importantly, by the non-existence of significant upward trends, which are consistent with this paper's empirical results. This conclusion can be verified in the following two aspects. First, from the standpoint of China's international investment position, the primary problem caused by the appreciation of the nominal exchange rate of RMB against USD is the deterioration of the balance sheet in the central bank due to valuation effect. According to the International Investment Position Table provided by the State Administration of Foreign Exchange, by the end of 2008, China's net international investment position was 1.519 trillion USD, accounting for $35.10 \%$ of the GDP over the same period. Specifically, if the nominal exchange rate of RMB against USD appreciates by $10 \%$, the losses of RMB value of net international investment assets caused by the valuation effect will reach about 3.5\% of the GDP over the same period. Therefore, the concern about the deterioration of the balance sheet is the core reason for the central bank's dislike of the appreciation of the nominal exchange rate of RMB against USD. Second, the central bank's significantly muted asymmetric preference for a nominal effective exchange rate reflects that the central bank's monetary policy is characterized by "a balance of comprehensive goals", and that the central bank is more concerned about employment and export-oriented development strategy. In other words, in the process of domestic economic structural adjustment, the central bank needs to stabilize external demand through appropriate exchange rate policies, which can gain time for the adjustments of domestic economic structure, and avoid extreme economic fluctuations brought by structural changes.

\subsection{The Re-Discussion on Different Behaviors of China's Central Bank over Its Loss Preferences for Exchange Rate}

The different behaviors of the central bank with regard to the loss preferences for the nominal exchange rate of RMB against USD and for an effective exchange rate indicate that China's central bank did not take the asymmetrical intervention as did the central banks in India, Korea, and other countries to prevent the appreciation of the bilateral nominal exchange rate against USD and nominal effective exchange rate. This paper holds that the central bank's exchange rate policies and behaviors are rational, which can be further confirmed in the following three aspects:

Firstly, when China's dualistic foreign exchange rate regimes were combined in 1994, the RMB-viewed in a longer term-went through a sharp devaluation against USD, which was coupled with a much higher inflation rate in China relative to that in the U.S. During the 1997 Asian financial crisis, the RMB was not obviously under-valued, and inflation rates in China and the U.S. were basically close. This position continued until mid-2005, and the relative purchasing power parity showed that the RMB exchange rate was basically at an "equilibrium" level. From mid-2005 to the end of 2006, when the reforms of market-oriented exchange rate regime were initiated, there was a clear appreciation of the RMB, together with a lower inflation rate in China than in the U.S. From 2007 to 2008, when China's inflation rate was higher than in that of the U.S., the RMB did not witness adjustment towards devaluation in the short term. Since then, the difference of inflation rates between China and the U.S. hasn't undergone obvious fluctuations (Figure 2). 


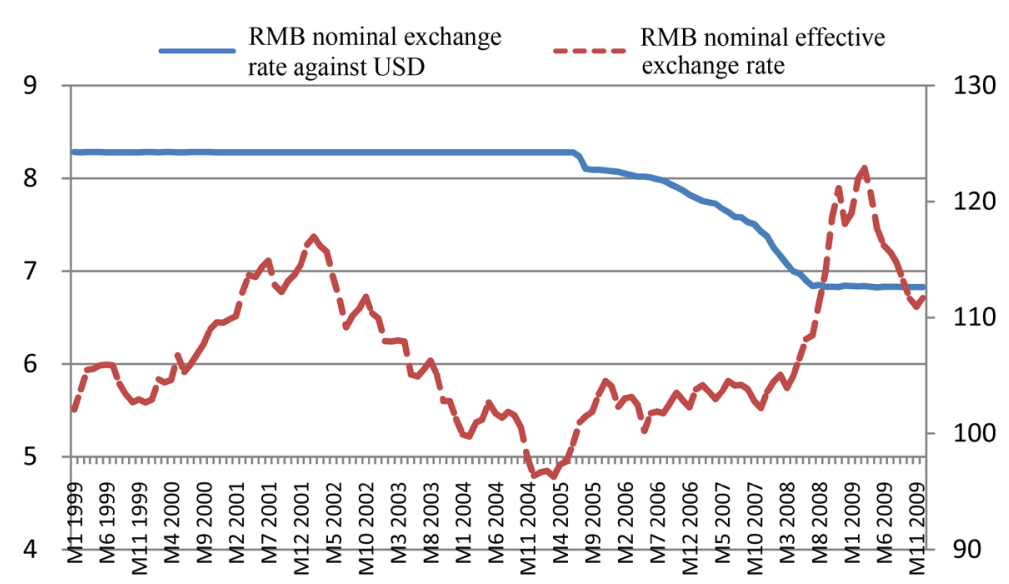

Figure 1. Trends of the nominal exchange rate of RMB against USD and RMB nominal effective exchange rate, 1999 M1 to 2009 M12.

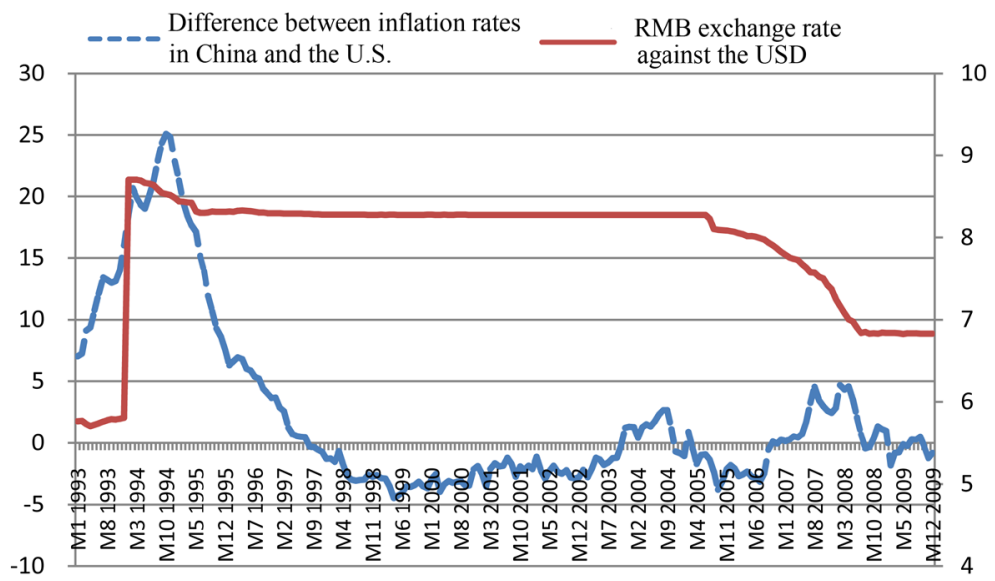

Figure 2. The difference between inflation rates in China and the U.S. (CPI, monthly data year-on-year) and the RMB nominal exchange rate against USD (monthly data).

Therefore, from a long-term perspective, the relative purchasing power parity shows that the central bank is not engaged in significant devaluation-oriented manipulation of RMB against USD, and the nominal exchange rate against USD appears more likely to follow an orderly movement along the "equilibrium" level. Also, China's central bank did not show preferences for the asymmetric losses brought about by the nominal exchange rate appreciation as did the central banks in some Southeast Asian countries such as India. This relatively stable exchange rate policy provided an effective nominal anchor between China's price level and that of the U.S. Moreover, it shows that when making RMB exchange rate policies, China, as a large trading country, has taken into account not only domestic interest but also the interests of its trading partners.

Secondly, we can look at it from the perspective of leading factors for China's economic growth. Since 1984, in order to expand its external demand and promote exports, China has adopted such measures as reduction and exemption of tariffs and value-added tax for imported inputs into processing trade. And the country has, since 1992, significantly reduced tariffs (especially the import tariffs on intermediary products) and adopted incentive measures such as import tariff exemption for capital goods with technical content, which has made the export of manufactured products a major driving factor for China's economic growth. The export proportions of manufactured goods, and machinery and transport equipment were $42.8 \%$ and $10.6 \%$ respectively in 1995 , and then moved up to $47.5 \%$ and $23.7 \%$ in 2007 . Although both exports, affected by the global financial crisis, decreased slightly in 2008, they still accounted for about $71 \%$ of China's total export. China's export-oriented development strategy is hailed as a successful model. The key to the success can be identified in the transition from creating comparative advantages through the export-oriented policy to spontaneously forming comparative ad- 
vantages via imported technologies, the economies of scale fostered by international and domestic markets, and the virtually unlimited supply of labor. Thus, with China's growing participation in international trade, an increasingly specialized pattern of division of labor is gradually developed (Wang Jinbin \& Li Nan, 2007). The formation of this global economic division of labor has taken shape under the double backdrop of "de-industrialization" and "outsourcing" of services in the developed countries and regions, and the rapid industrialization of China. It therefore possesses a certain degree of rigidity.

Furthermore, according to the statistics from the website of the Ministry of Commerce, in 2002, China's exports to the European Union, the U.S., Japan and South Korea accounted respectively for 14.8\%, 21.5\%, 14.9\% and $4.8 \%$ of China's total exports, and these figures changed to $20.5 \%, 17.7 \%, 8.0 \%$ and $5.3 \%$ in 2008 (data from January to October). The EU has become China's largest exporting destination, while the ratios of China's direct exports to the U.S. and Japan have decreased obviously. Given the changes in trade structure, it is essential to continue with the strategy of promoting China's exports to boost its growth, to prevent the entry of a nominal effective exchange rate into a one-way channel of appreciation, and to prevent adverse impacts brought about by a "hard landing" in the process of domestic economic structural adjustments. From this perspective, the growth of China's foreign exchange reserves can be viewed more as the by-product of the export-oriented strategy.

Finally, as to exchange rate policy, the central bank mainly adopts the USD system for reserves ${ }^{7}$, and adopts a basket of currencies for trade. Such asymmetry in the financial and trade strategies reflects precisely the current asymmetry in the international financial and trading system. When examining the changing tendency of the proportion of USD in international trade in the 1990s, we find that the import and export by the U.S. accounted for $16.6 \%$ of total world import and export in 1992, and reached a high point of $19.45 \%$ in 2000, which was followed by a decline until $13.37 \%$ in $2008^{8}$. In contrast, the proportion of USD in international transactions and reserves by the end of 2003 was $70 \%$, while that of the euro was 20\%, and the British pound and Japanese yen accounted for only less than $10 \%$ (BIS, 2004). The euro, as an alternative to the USD, has witnessed improvement in international reserves since the 2008 financial crisis, and achieved a record high of $27 \%$ in global currency reserves in the second quarter of 2009, while the USD dropped to the lowest level of $62.8 \%$ in a decade (IMF, 2009). Although the birth of the euro eroded the international market share of the USD, the latter still remains the dominant international reserve currency by relying on a more developed financial market than Europe (Galati \& Wooldridge, 2009). Therefore, the trends revealed by a nominal exchange rate of RMB against USD and the relative purchasing power parity are basically consistent, while the nominal effective exchange rate reflects that it is a reasonable choice for exchange rate policies and practices to serve the purpose of the development strategy by promoting exports.

From the above viewpoint regarding China's economic growth model, and the asymmetry of international financial and trade systems, this paper believes that the central bank does not exhibit a preference for asymmetric losses in the exchange rate of RMB against USD, and displays an exceedingly muted preference for asymmetrical losses on the nominal effective exchange rate, which is a rational choice. The exchange rate policies and practices, which reflect the actual asymmetry in current international financial and trading systems, will not only serve China's economic growth model, but also take into account the interests of many parties. Because of its rationality, the basic direction of such an exchange rate policy will continue in the future, but it will need to bear the losses of net international investment position due to valuation effect. Furthermore, because the central bank does not have "asymmetric preferences" for the nominal exchange rate of RMB against USD, in view of imported inflation pressure and trade structural changes, the RMB nominal exchange rate appreciation against USD will increase the losses caused by valuation effect. Therefore, the effect of the exchange rate policy will be substantially enhanced through questing for a more reasonable form of foreign exchange reserve management, so as to reduce the losses caused by valuation effect.

\section{Brief Conclusion}

This paper studied the exchange rate policy of China's central bank by dint of ALP function for the first time. The results indicate that the central bank's performance does not manifest the ALP on the policies and behaviors

\footnotetext{
${ }^{7}$ Though the central bank does not publish the structure of foreign exchange reserves, yet publishes the total volume denominated in USD, it is generally assumed that USD assets account for approximately 70\% of the total volume.

${ }^{8}$ Calculated on the U. S. trade statistics provided by International Economic Accounts (BEA) and the global trade statistics provided by Direction of Trade Statistics (IMF).
} 
involving the nominal exchange rate of RMB against USD; while on the nominal effective exchange rate, the central bank's performance displays an exceedingly muted asymmetrical loss of preference, especially since the reform of the foreign exchange rate regime. This indicates that the concern by the central bank for the localcurrency-denominated losses of net international investment position caused by the valuation effect of nominal exchange rate appreciation in the RMB against USD is smaller than that for the weakening of export product's competitiveness brought about by the appreciation of the RMB nominal effective exchange rate.

With regard to the preferences between the losses caused by appreciation of nominal exchange rate of the RMB against USD and that caused by appreciation of effective exchange rate, the different behaviors by the central bank may be in line with both the established models of China's economic growth. China needs a stable external demand to promote economic growth, provide a buffer for domestic economic restructuring, and avoid large negative impacts caused by extreme structural changes. However, the valuation loss brought about by RMB appreciation has become an important issue that cannot be ignored. Therefore, how to more effectively manage foreign exchange reserves to lower the loss of valuation effect, and—in the meanwhile-more skillfully manage the nominal effective exchange rate to maintain external demand, will be the essential goals of China's exchange rate policy.

\section{References}

Aizenman, J., \& Lee, J. (2005). International Reserves: Precautionary versus Mercantilist Views, Theory and Evidence. NBER, Working Paper No. 11366.

Aizenman, J., \& Marion, N. (2003). The High Demand for International Reserves in the Far East: What's Going On? Journal of Japanese and International Economics, 17, 370-400. http://dx.doi.org/10.1016/S0889-1583(03)00008-X

Bank for International Settlements (BIS) (2004). 74th Annual Report.

Bussière, M., \& Mulder, C. B. (1999). External Vulnerability in Emerging Market Economies—How High Liquidity Can Offset Weak Fundamentals and the Effects of Contagion. IMF, Working Paper No. 88.

Calvo, G., \& Reinhart, C. (2002). Fear of Floating. Quarterly Journal of Economics, 117, 379-408. http://dx.doi.org/10.1162/003355302753650274

Cheung, Y.-W., Chinn, M., \& Fujii, E. (2007). China’s Current Account and Exchange Rate. In R. Feenstra, \& S.-J. Wei (Eds.), China's Growing Role in World Trade (pp. 231-271). Chicago: University of Chicago Press.

Chit, M. M., Rizov, M., \& Willenbockel, D. (2008). Exchange Rate Volatility and Exports: New Empirical Evidence from the Emerging East Asian Economies. Middlesex University Economics and Statistics, Discussion Paper No. 127.

Dooley, M. P., Folkerts-Landau, D, \& Garber, P. (2003). An Essay on the Revived Bretton Woods System. NBER, Working Paper No. 9971.

Fan, Z. Y. (2008). Valuation Effect and the External Balance Adjustment of China-Study on Exchange Rate Risk of Foreign Exchange Reserves. Macro-Economy Forum at Renmin University of China, Working Paper of the 3rd Quarter.

Galati, G., \& Wooldridge, P. (2009). The Euro as Reserve Currency: the Challenge to the Pre-eminence of the US Dollar. International Journal of Finance \& Economics, 14, 1-23. http://dx.doi.org/10.1002/ijfe.379

Ghosh, A., \& Rajan, R. S. (2007) A Survey of Exchange Rate Pass-Through in Asia: What does the Literature Tell us? Asia Pacific Economic Literature, 21, 13-28.

Higgins, M., \& Klitgaard, T. (2004) Reserve Accumulation: Implications for Global Capital Flows and Financial Markets. Current Issues in Economics and Finance, No. 10, Federal Reserve Bank of New York.

Lane, P., \& Milesi-Ferretti, G. M. (2004). Financial Globalization and Exchange Rates. Mimeo, IMF.

Levy-Yeyati, E. L., \& Sturzenegger, F. (2007). Fear of Floating in Reverse: Exchange Rate Policy in the 2000s. Mimeo.

Machlup, F. (1966). The Need for Monetary International Reserves. Reprints in International Finance 5, Princeton University.

Marquez, J., \& Schindler, J. (2007). Exchange-Rate Effects on China’s Trade. Review of International Economics, 15, 837853. http://dx.doi.org/10.1111/j.1467-9396.2007.00700.x

Mckinnon, R., \& Schnabl, G. (2004). The East Asian Dollar Standard, Fear of Floating, and the Original Sin. Review of Development Economics, 8, 331-360. http://dx.doi.org/10.1111/j.1467-9361.2004.00237.x

Nobay, R. A., \& Peel, A. D. (2003). Optimal Discretionary Monetary Policy in a Model of Asymmetric Central Bank Preference. The Economic Journal, 113, 657-665. http://dx.doi.org/10.1111/1468-0297.t01-1-00149

Pontines, V., \& Rajan, S. R. (2008). “Fear of Appreciation” Not “Fear of Floating?” Foreign Exchange Market Intervention in Emerging Asia. Mimeo. 
Ramachandran, M., \& Srinivasan, N. (2007). Asymmetric Exchange Rate Intervention and International Reserve Accumulation in India. Economics Letters, 94, 259-265. http://dx.doi.org/10.1016/j.econlet.2006.06.040

Ruge-Murcia, F. J. (2003). Inflation Targeting under Asymmetric Preferences. Journal of Money, Credit and Banking, 35, 763-785. http://dx.doi.org/10.1353/mcb.2003.0038

Song, X. J., Chen, D. B., \& Ren, R. E. (2006). Analysis on the Valuation Effect in China’s Adjustment of External Balance. Studies of International Finance, 3, 57-61.

Srinivasan, N., Mahambare, V., \& Ramachandran, M. (2009). Preference Asymmetry and International Reserve Accretion in India. Applied Economics Letters, 16, 1543-1546. http://dx.doi.org/10.1080/13504850701578942

Stock, J. H., \& Watson, M. W. (2002). Has the Business Cycle Changed and Why? NBRE Macroeconomics Annual, 2002, 159-230.

Surico, P. (2008). Measuring the Time Inconsistency of US Monetary Policy. Economica, 75, 22-38.

Thorbecke, W., \& Zhang, H. (2008). The Effect of Exchange Rate Changes on China's Labor-Intensive Manufacturing Exports. RIETI Discussion Paper Series, No. 038.

Varian, H. (1975). A Bayesian Approach to Real Estate Assessment. In S. E. Feinberg, \& A. Zeller (Eds.), Studies in Bayesian Economics in Honour of L. J. Savage (pp. 195-208). Amsterdam: North Holland.

Wang, J. B., \& Li, N. (2007). The Cause, Present Situation and Perspective of China's Trade Surplus. Economic Theory and Business Management, 11, 24-33.

Zeller, A. (1986). Bayesian Estimation and Prediction Using Asymmetric Loss Function. Journal of the American Statistical Association, 81, 446-451. http://dx.doi.org/10.1080/01621459.1986.10478289 